\title{
Translating English slang into Ukrainian: A study of Pulp Fiction and Once Upon a Time in... Hollywood
}

\author{
Kateryna Bondarenko ${ }^{1 *}$, Oleksandr Bondarenko ${ }^{1}$ \\ ${ }^{1}$ Volodymyr Vynnychenko Central Ukrainian Pedagogical University, 25009, Kropyvnytskyi, \\ Ukraine
}

\begin{abstract}
This research focuses on translation strategies and techniques for rendering slang in Quentin Tarantino's films "Pulp Fiction" and "Once Upon a Time in Hollywood". The material of the research was the original scripts for the films and their translations into Ukrainian. Defining translation strategies when transferring English slang into Ukrainian involved: frequency analysis of the slang words; semantic decomposition of the slang words to establish their meanings; and comparison of the words to reveal consistent patterns of translating English slang into Ukrainian. Slang words fucking, fuck, shit, goddamn, motherfucker make up $3.6 \%$ of the total wordcount in "Pulp Fiction" and $1.33 \%$ in "Once Upon a Time in... Hollywood". They mainly function as exclamations, nominations for something inferior, as euphony, or to denote a despicable adversary. Literal translation has been registered in $31.73 \%$ in "Pulp Fiction" and $30.98 \%$ in "Once Upon a Time in Hollywood", explicitation $(6.07 \%$ and $26.03 \%$, ) substitution $(39.75 \%$ and $48.8 \%)$. Slang words were neutralised in $15.45 \%$ and $16.8 \%$, omitted in $21.34 \%$ and $21.72 \%$. The study hypothesises that the techniques involved show a correlation between the semantic transparency of the slang word and the strategy chosen.
\end{abstract}

\section{Introduction}

Rendering slang words is one of the problems audiovisual translators are often confronted. In this paper we focus on "Pulp Fiction" and "Once Upon a Time in... Hollywood" by Quentin Tarantino with a special attention paid to slang words and their translation into Ukrainian.

Quentin Tarantino's films are noted for their ambiguity, but the notorious violence often gives his characters depth which make such aggressive content more morally justifiable. The films usually trigger overreaction both from audiences and critics (1-4), with "Pulp Fiction" (1994) and "Once Upon A Time in... Hollywood" (2019) being no exception due to their utter polysemiotic character "comprising several signifying codes that operate simultaneously in the production of meaning" (5: 16).

\footnotetext{
* Corresponding author: katerinabond@gmail.com
} 
The object of this study is centred on the textual (verbal) component of the films, and more particularly on the offensive or rude language (6), mainly represented by slang words, frequently used in the source text and rendered into Ukrainian in translation. Slang is a sublanguage used to make the level of discourse more informal, refuse conventions or ease social exchanges. (General) slang is not group-restricted as argots or jargons that (re)create social identity. Slang is extremely innovative and expressive. The contextual analysis proves that slang may serve heterogeneous purposes and trigger different, even divergent effects: from sympathy to jocularity and offensiveness. Some expressions may be quite neutral when used in jest to mock people, but become quite offensive when used with sarcastic intonation or in a conflict situation (even more in audiovisual products that literally reconstruct those factors). It should be noted, that slang is a kind of a grey area that shares boundaries with colloquialisms or taboo words. Most scholars indicate that obscene words should be considered a subcategory of slang as its most elemental phenomena. Some slang words can be described as verbal weapons because they are meant to insult or demean people (7). Besides, all the obscene words detected in the films are registered in numerous slang dictionaries $(7,8,9,10)$. "Slang is the language that says no. Born in the street it resists the niceties of the respectable. It is impertinent, mocking, unconvinced by rules, regulations and ideologies. It is a subset of language that since its earliest appearance has been linked to the lower depths, the criminal, the marginal, the unwanted or even persecuted members of society. It has been censored, ignored, shoved to one side and into the gutter from where it is widely believed to take its inspiration and in which it and its users have a home. It remains something apart, and for many that is where it should stay" (11: 6). The "lower" register of slang makes it suitable for characterising the characters: gangsters in "Pulp Fiction", and the criminal group Manson's family in "Once Upon a Time in... Hollywood". Slang is understood as socially unmeasured, substandard language, highly expressive and evaluative, characterised by limited functionality and overlexicalization of certain domains. The deeper psychological understanding of slang makes us think of defence of the ego against the superego and our simultaneous eagerness and reluctance to be human. Slang resembles (and often embraces) profanity, since it substitutes destructive physical action. It is used mainly not to communicate ideas, but rather an attitude, a feeling, or a verbal action (9).

"Pulp Fiction" articulates the semiotics of gangster genre, identifies the gangsters with the corruption of the society (a symbol of popular and mass culture) (12). The main characters in this movie are "a bunch of gangsters doing a bunch of gangsters' shit, who speak and swear as real gangsters are supposed to speak and swear" (13: 16). The plot of "Once Upon a Time in Hollywood" is set in 1969 and involves the killing of a young pregnant actress Sharon Tate by the gang called "Manson Family". The main characters actor Rick Dalton and his backup Cliff Booth - are going through a crisis in their film careers during Hollywood's golden age (1).

Ukrainian translation of "Pulp Fiction" was performed by ICTV studio in 1995, while "Once Upon a Time in... Hollywood" was translated by Oleh Kolesnikov and LeDoyen Studio in 2019. The translations were highly appreciated by both the audience and the professional translation community.

The study aims at determining translation strategies and techniques for rendering English slang in "Pulp Fiction" and "Once Upon a Time in... Hollywood". Audiovisual translation is understood here as translation of verbal elements of an audiovisual text (14). Employing frequency analysis, semantic decomposition and contextual analysis of the slang words in "Pulp Fiction" and "Once Upon a Time in... Hollywood", the paper explains translation strategies and techniques. 


\section{Methods}

Swearing (using obscene slang words) is so frequent in both films that it should be accepted as the basis of protagonists' idiolects. One of the tasks of the research was to determine the slang words' frequency by statistical analysis.

The overall wordcount in the English scripts for "Pulp Fiction" is 168,755, of which there are 316 slang words instances analysed. For "Once Upon a Time in... Hollywood" the wordcount for the English scripts is 89,952, of which there are 167 instances. The scripts taken as corpora were analysed with the program WordSmith Tools to acquire a list of words that appear statistically more often in the texts. The analysis focused primarily on the frequency rather than the semantic, grammatical, or pragmatic levels. Still examination of dispersion patterns and concordances are also useful supplementary forms of analysis. It should be noted, however, that despite the obvious scientific appeal of statistical analysis results, the results should be verified and supplemented by analysis at other language levels and other methods (15).

When discussing translation strategies, 'foreignization' and 'domestication' are used respectively for a translation strategy which is source-text oriented, word for word, structure for structure and literal; and for that which is target text-oriented, free, natural, transparent and message for message (16). It is widely known that slang words are not used in a literal but in an emotive sense (13). Moreover, their literal meanings are sometimes faded or completely lost. As such, the translation of slang is not merely translating lexical items from a source language into a target language. It is a process of rendering the style (register) of language and, therefore, the culture of a source language into a target language. The concept of translation strategy varies at the macro- and micro-levels and some scholars claim that neutralization, toning up or down are "translation strategies" for rendering multidimensional linguistic phenomena, such as idioms or slang (17).

A translation technique is a micro method for operationalizing a general or globalizing translation strategy. Each strategy involves certain techniques contributing to the objectives: literal translation, borrowing, calque, explicitation, substitution, transposition, compensation, omission, reformulation, etc. (18).

Semantic decomposition of words has been used in the study to define the whole scope of meanings they may acquire. Further on the content analysis of the words encountered has been performed to detect the words' exact meanings in the films. Maintaining semantic structure and transferring the functions the words entail in the original is one of the most successful solutions. Still, there is always some kind of difference, semantic or pragmatic, which prevents the translation from functioning in exactly the same manner as the original text. The tone appropriateness presumably becomes as important as the semantic equivalence. Comparative analysis of the source scripts and their translations has been carried out to detect the techniques adopted by the translators.

The data have been classified according to the translation techniques and strategies with a special emphasis on meaning in context. The hypothesis was that the semiotic principle of transparency, mainly semantic transparency, leads to semantic predictability (19) and potential translatability of the slang words.

\section{Research results}

The present paper attempts to explore problems the translators encounter when dealing with obscene slang words and to define predominant strategies and the most productive techniques applied. The Ukrainian translations of "Pulp Fiction" and "Once Upon a Time in... Hollywood" serve as the sources for data and are used for illustrative purposes. Some 
regular English-Ukrainian correspondences of obscene slang words in Tarantino's films will also be provided.

Our data from films scripts' analysis performed by WordSmith 6.0 have shown that slang words are among the most frequent meaningful words both in "Pulp Fiction" and "Once Upon a Time in... Hollywood".

WordSmith Tools 8.0 Word list (Pulp.Fiction)

\begin{tabular}{|c|c|c|c|c|c|c|c|c|}
\hline $\mathbf{N}$ & Word & Freq. & $\%$ & Texts & $\%$ & Dispersion & Lemmas & Set \\
\hline \multicolumn{2}{|c|}{29 FUCKIN } & 93 & 0,57 & 1 & 100,00 & 0,61 & & \\
\hline \multicolumn{2}{|c|}{40 SHIT } & 75 & 0,46 & 1 & 100,00 & 0,58 & & \\
\hline \multicolumn{2}{|c|}{50 FUCK } & 66 & 0,40 & 1 & 100,00 & 0,69 & & \\
\hline \multicolumn{2}{|c|}{101 FUCKING } & 29 & 0,18 & 1 & 100,00 & 0,57 & & \\
\hline \multicolumn{2}{|c|}{111 GODDAMN } & 27 & 0,16 & 1 & 100,00 & 0,66 & & \\
\hline & THERFUCKER & 26 & 0,16 & 1 & 100,00 & 0,57 & & \\
\hline
\end{tabular}

Fig. 1. Word frequency in the scripts of "Pulp Fiction"

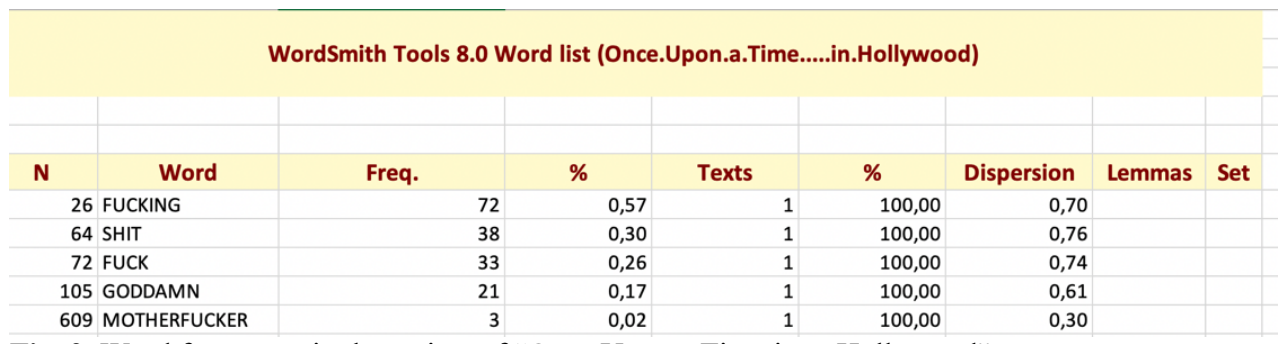

Fig. 2. Word frequency in the scripts of "Once Upon a Time in... Hollywood"

The following fragment contains more or less half of the slang words omitted in the translation presumably due to the high tempo and emotional load of the scene:

ST: 01:17:50,506 --> 01:17:52,474 Fucking damn it, Rick, I swear to God.

01:17:52,608 --> 01:17:54,811 Forgot your fucking lines, embarrassed yourself

01:17:54,943 --> 01:17:57,145 like that in front of all those goddamn people!

01:17:57,278 --> 01:18:00,248 You were drinking all night, fucking drinking again,

01:18:00,382 --> 01:18:03,252 eight goddamn fucking whiskey sours

01:18:03,385 --> 01:18:06,455 Fucking bullshit.

01:18:08,491 --> 01:18:10,761 You're a fucking miserable drunk.

01:18:10,894 --> 01:18:13,196 Not fucking remembering your fucking lines.

TT: 01:17:50,506 --> 01:17:52,474 Щоб ти скиснув, Рік, бляха муха!

01:17:52,608 --> 01:17:54,811 Забув увесь текст!

01:17:54,943 --> 01:17:57,145 І так зганьбився перед цими чортовими покидьками!

01:17:57,278 --> 01:18:00,248 Бо ти ж хиляв цілу ніч, бухав знову, сука!

01:18:00,382 --> 01:18:03,252 Вісім довбаних віскі сауер!

01:18:03,385 --> 01:18:06,455 Всрався таки, курво!

01:18:08,491 --> 01:18:10,761 Паскудний, кінчений алкаш!

01:18:10,894 --> 01:18:13,196 Забув увесь текст, бездарний гандон! ("Опсе Upon a Time in... Hollywood")

Slang words are mainly polysemous and the question of whether polysemy is a stable semantic structure or whether a word embodies its meaning only in context is still unresolved. We first resorted to four slang dictionaries to observe the full scope of meanings the words under analysis may hypothetically acquire. The words under analysis were fuck, fucking, shit, motherfucker and goddamn. The lexicographic sources were "Dictionary of contemporary slang" by T. Thorne, "Dictionary of American slang" by B. A. Kipfer and R. L. Chapman, "Oxford dictionary of modern slang" by Ayto, J., Simpson, J. and "American Slang Dictionary: The Ultimate Reference to Nonstandard Usage, 
Colloquialisms, Popular Jargon and Vulgarisms" by R. A. Spears (7, 8, 9, 10). The entries' analysis resulted in the following data systematically collected by consulting slang dictionaries.

Fuck and fucking mean much more than just 'related to sex' (20). Fuck may function as a noun to nominate something or somebody obnoxious, disgusting or contemptible; as a verb to denote destruction (of sb's trust (to cheat, to swindle, take advantage of) or sb's possessions (to botch and confuse, ruin). Fucking may serve as an intensifier used with other adjectives for emphasis or an adjective with overall negative meaning of 'displeasing', 'despicable', 'damnable', 'lousy', 'cursed', 'wretched', 'rotten', 'accursed'.

Aside from the literal meaning 'to defecate', shit implies destructive actions 'to browbeat, to annoy (someone), to deceive, bamboozle, confuse someone'. Derived from the literal meaning of 'excrement', shit as a noun serves to nominate something or somebody obnoxious, disgusting, despicable, contemptible.

Enantiosemy holds a particular interest for slang studies since "Semantic opposition within one lexeme is a rare phenomenon in contemporary languages and is justly regarded as undesirable" (21:132). Two of the studied words show the coexistence of one meaning and its opposite within one polysemantic lexeme. Motherfucker may nominate both a 'problem or difficulty' and a 'fine, interesting, or remarkable event', while shit may characterize something or someone 'awful and inferior' as well as 'excellent and admirable'.

Another important objective of the paper was to analyse contexts in which slang words were used, focusing on pragmatic purposes and effects. The corpus-based evidence proves that the same word may function differently throughout the texts. For instance, the "Concordance" module shows quite a number of different collocational sets of the slang words in "Pulp Fiction" and "Once Upon a Time in... Hollywood".

WordSmith Tools 8.0 concordance list for fuck in "Once Upon a Time in ... Hollywood"

\begin{tabular}{|c|c|c|c|c|}
\hline \multicolumn{5}{|c|}{ (100 characters saved per entry) } \\
\hline $\mathbf{N}$ & Concordance & Set & Tag & v \\
\hline $1 \mathrm{i}$ & ing tickets. Cliff drives him everywhere now. Oh, fuck. Well, sounds like a good friend. - I try. - Mm. I & FUCK & & \\
\hline $2 y$ & you? - Yeah. And let me tell you, that-that's one shit-fuck crazy weapon $y-y$-you do not wanna be on the wrong & FUCK & & \\
\hline 3 & 't worth crying about, then I don't know what the fuck is. Right. That guy in there turn you down? No. H & FUCK & & \\
\hline 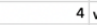 & whether I cry in public. Nobody remembers who the fuck I am anyway, huh? ....at the Hall of Justice here. & FUCK & & \\
\hline 5 r & ng of Kennedy - was the product of a sick mind. - Fuck! - Thank you. Hey, let's go. - Take me home, Cliff & FUCK & & \\
\hline $6 \mathrm{t}$ & that one of these days, that Polish prick's gonna fuck things up, and when he does, Jay's gonna be there & FUCK & & \\
\hline 7 & ear-old boys. Yeah. I never stood a chance. Argh. Fuck you, Dr. Sapirstein. Oh, here we are. Tell transp & FUCK & & \\
\hline $8 t$ & thole of a boat. Yeah. H-he's a goddamn war hero. Fuck. Yeah, appreciate it. Okay, you fucking horse's as & FUCK & & \\
\hline 91 & Try that again. Whoa, whoa, whoa, whoa. What the fuck is going on here? Hey, jackass, this is our serie & FUCK & & \\
\hline $10 ?$ & ? Hey, jackass, this is our series lead. What the fuck are you thinking? You're right, Janet. I'm sorry & FUCK & & \\
\hline $11 \mathrm{t}$ & t of Bruce. What? - Hey, Randy. - Cliff. What the fuck, man? Let me just say, nobody beat the shit out of & FUCK & & \\
\hline 12 & ar says something different. Oh, my God! What the fuck did you do to my car?! What the fuck did you do $t$ & FUCK & & \\
\hline 13 & od! What the fuck did you do to my car?! What the fuck did you do to her car? I threw this little prick & FUCK & & \\
\hline 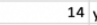 & y he uses those boots to step on people. What the fuck was that?! Jesus Christ! Fuck! Piece of shit. Fuc & FUCK & & \\
\hline 15 & on people. What the fuck was that?! Jesus Christ! Fuck! Piece of shit. Fucking damn it, Rick, I swear to & FUCK & & \\
\hline 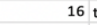 & them! You're sitting there like a fucking baboon! Fuck! Eight fucking whiskey sours. I couldn't stop at $f$ & FUCK & & \\
\hline 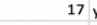 & yourself. You're gonna stop fucking drinking. Oh, fuck it. Damn it! You show that little fucking girl.Y & FUCK & & \\
\hline 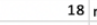 & nna show them on that goddamn fucking set who the fuck Rick Dalton is, all right? Let me tell you someth & FUCK & & \\
\hline 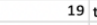 & ter? Okay. - It's great. Hey! Hi. Huh. Woo! Shit. Fuck you, you fucking pig! Oh, no. Hello, hot stuff. L & FUCK & & \\
\hline 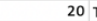 & That's you. Yeah. Obviously, I'm not too young to fuck you. But obviously, you are too old to fuck me. W & FUCK & & \\
\hline
\end{tabular}

Fig.3 Concordance list for fuck in "Once Upon a Time in... Hollywood" 


\begin{tabular}{|c|c|c|c|}
\hline \multicolumn{4}{|c|}{ WordSmith Tools 8.0 concordance list for fuck in "Pulp Fiction" } \\
\hline \multicolumn{4}{|c|}{ (100 characters saved per entry) } \\
\hline \multirow[t]{21}{*}{$\mathbf{N}$} & & Concordance & Set \\
\hline & & robbery. They're insured. Why should they give a fuck? I don't even need a gun in a Federal bank. Heard & FUCK \\
\hline & 2 & hese places are insured. Manager. He don't give a fuck. They're just trying to get you out before you sta & FUCK \\
\hline & 3 & back gettin' paid $\$ 1.50$ an hour ... really give a fuck you're stealin' from the owner? Customers sittin' & FUCK \\
\hline & 4 & ot the metric system. They wouldn't know what the fuck a Quarter-Pounder is. - What do they call it? - T & FUCK \\
\hline & 5 & t of Marsellus Wallace's wife. - So what he'd do? Fuck her? - No, no, no, no, no. Nothin' that bad. - We & FUCK \\
\hline & 6 & or nothin'. Would you give a guy a foot massage? Fuck you. - You give 'em a lot? - Fuck you. - You know & FUCK \\
\hline & 7 & a foot massage? Fuck you. - You give 'em a lot? - Fuck you. - You know, I'm kind of tired. I could use a & FUCK \\
\hline & 8 & ... like a bitch? - Nol - Then why you tryin' to fuck him like a bitch? - I didn't. - Yes, you did. Yes & FUCK \\
\hline & 9 & - Yes, you did. Yes, you did, Brett! You tried to fuck him. - No, no. But Marsellus Wallace don't like $t$ & FUCK \\
\hline & 10 & el a slight sting. That's pride fuckin' with you. Fuck pride! Pride only hurts. It never helps. You figh & FUCK \\
\hline & 11 & hit than fuckin' with a man's automobile? - Don't fuck with another man's vehicle. - You don't do it. - & FUCK \\
\hline & 12. & - He was $d d$ Oh, yes he was. $d$ Let's go. What the fuck is this place? This is Jackrabbit Slim's. An Elvi & FUCK \\
\hline & 13 & mebody really special. When you can just shut the fuck up for a minute and comfortably share silence. We & FUCK \\
\hline & 14 & us fucking Christ. You fu - Oh, Jesus Christl Oh, fuck me. Fuck mel Oh- Come on, girl. We're gettin' out & FUCK \\
\hline & 15 & g Christ. You fu - Oh, Jesus Christl Oh, fuck me. Fuck mel Oh- Come on, girl. We're gettin' outta here. & FUCK \\
\hline & 16 & We gotta walk now. Don't fuckin' die on me, Mia! Fuck! Answer. Have you got the ring? - Why, certainly. & FUCK \\
\hline & 17 & ase! Please! Yes, yes. Hold hands, you lovebirds. Fuck you, Lance! Answer! Now what do you say? I give u & FUCK \\
\hline & 18 & Shit. It's $1: 30$ in the goddamn morning. What the fuck's going on out here? Who's she? Go to the fridge an & FUCK \\
\hline & 19 & O.D.ing! - Get her outta here! - Get the shot! - Fuck you! Fuck you too! - What a fuckin' bitch. Just k & FUCK \\
\hline & 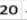 & - Get her outta here! - Get the & FUCK \\
\hline
\end{tabular}

Fig.4 Concordance list for fuck in "Pulp Fiction"

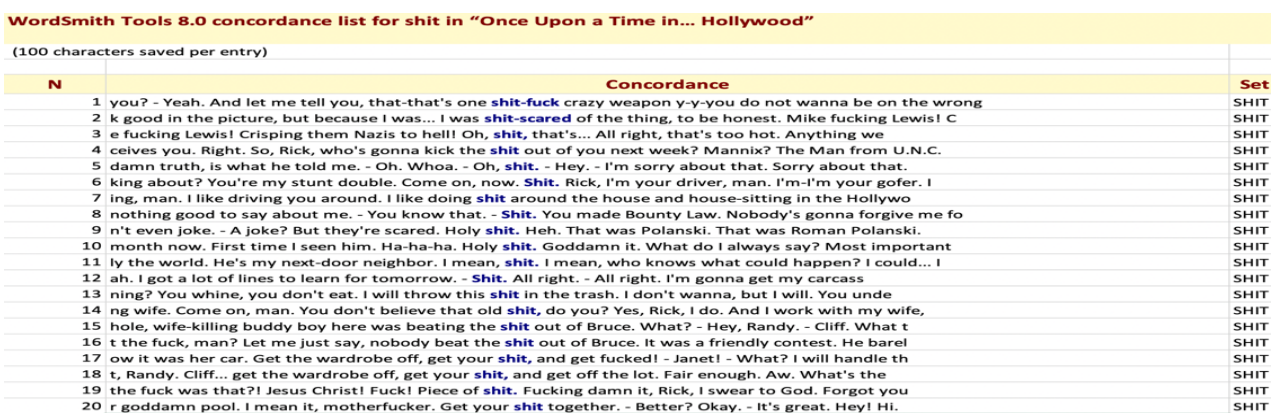

Fig.5 Concordance list for shit in "Once Upon a Time in... Hollywood"

WordSmith Tools 8.0 concordance list for shit in "Pulp Fiction"|

\begin{tabular}{|c|c|c|}
\hline \multicolumn{3}{|c|}{ (100 characters saved per entry) } \\
\hline $\mathbf{N}$ & Concordance & Set \\
\hline 1 & Forget it. It's too risky. I'm through doing that shit. You always say that. The same thing every time." & SHIT \\
\hline 2 & the little differences. I mean, they got the same shit over there that they got here, - but it's just th & SHIT \\
\hline 5 & e foot fuckin' master. - You given a lot of them? Shit, yeah! Got my technique down and everything. I don & SHIT \\
\hline 6 & house, fuckin' up the way the nigger talks; that shit ain't right. Motherfucker do that shit to me, he & SHIT \\
\hline 7 & alks; that shit ain't right. Motherfucker do that shit to me, he better paralyze my ass, 'cause I kill t & SHIT \\
\hline 8 & This ain't a man with a sense of humor about this shit. You know what l'm sayin'? It's an interestin' poi & SHIT \\
\hline 11 & $n$ theel" I think you gonna find ... when all this shit is over and done - I think you're gonna find your & SHIT \\
\hline 12 & nly hurts. It never helps. You fight through that shit. 'Cause a year from now, when you kickin' it in th & SHIT \\
\hline 13 & kes, and that's it. Hey, my name's Paul, and this shit's between y'all. Then what'd you fuckin' ask me abo & SHIT \\
\hline 14 & ong with these two. This is real, real, real good shit. But this one is a fuckin' madman. Remember, 1 jus & SHIT \\
\hline 15 & e people who know the difference ... between good shit and bad shit, this is the house they come to. Now & SHIT \\
\hline 16 & know the difference ... between good shit and bad shit, this is the house they come to. Now, my shit, Il & SHIT \\
\hline 17 & bad shit, this is the house they come to. Now, my shit, I'll take the Pepsi Challenge with that Amsterdam & SHIT \\
\hline 18 & I'll take the Pepsi Challenge with that Amsterdam shit $\ldots$ any old day of the fuckin' week. - That's a b & SHIT \\
\hline
\end{tabular}

Fig.6 Concordance list for shit in "Pulp Fiction".

It is arguably legitimate to provide qualitative analysis of the slang words' semantic ambiguity in the studied films with regard to the meanings they convey in the analysed audiovisual products. While studying collocation sets provided by WordSmith Tools, it soon appeared that it was possible to divide the examples into relatively distinct groups and establish an approximate typology of cases with regard to their meanings. The slang words' frequency in the films was the following: fucking (fuckin) (122 cases in "Pulp Fiction", 72 in "Once Upon a Time in... Hollywood"), fuck (66 cases in "Pulp Fiction", 33 in "Once Upon a Time in... Hollywood"), shit (75 cases in "Pulp Fiction", 38 in "Once Upon a Time in... Hollywood"), goddamn (27 cases in "Pulp Fiction", 21 in "Once Upon a Time in... Hollywood"), motherfucker (26 cases in "Pulp Fiction", 3 in "Once Upon a Time in... Hollywood"). The percentage below was calculated from this data. 
Table 1. Semantic ambiguity of fucking in "Pulp Fiction" and "Once Upon a Time in ... Hollywood"

\begin{tabular}{|c|c|c|c|}
\hline \multirow{2}{*}{ Film } & \multicolumn{3}{|c|}{ Meaning (function) } \\
\cline { 2 - 4 } & $\begin{array}{c}\text { intensifier used with other } \\
\text { adjectives for emphasis }\end{array}$ & $\begin{array}{c}\text { wretched, rotten, accursed, } \\
\text { damnable, lousy, cursed }\end{array}$ & $\begin{array}{c}\text { extremely, } \\
\text { very }\end{array}$ \\
\hline "Pulp Fiction" & $61 \%$ & $30 \%$ & $9 \%$ \\
\hline $\begin{array}{c}\text { "Once Upon a Time } \\
\text { in... Hollywood" }\end{array}$ & $68 \%$ & $36.1 \%$ & $8.3 \%$ \\
\hline
\end{tabular}

Table 2. Semantic ambiguity of fuck in "Pulp Fiction" and "Once Upon a Time in ... Hollywood"

\begin{tabular}{|c|c|c|c|c|c|c|}
\hline \multirow{2}{*}{ Film } & \multicolumn{6}{|c|}{ Meaning (function) } \\
\cline { 2 - 7 } & $\begin{array}{c}\text { an } \\
\text { exclamation } \\
\text { of disgust, } \\
\text { dismay }\end{array}$ & $\begin{array}{c}\text { to } \\
\text { copulate } \\
\text { with }\end{array}$ & $\begin{array}{c}\text { to cheat, } \\
\text { swindle, } \\
\text { maltreat, } \\
\text { to ruin }\end{array}$ & $\begin{array}{c}\text { misfortune, } \\
\text { hostile } \\
\text { behavior, } \\
\text { ill-treatment }\end{array}$ & $\begin{array}{c}\text { an } \\
\text { obnoxious, } \\
\text { disgusting } \\
\text { person }\end{array}$ & excellent \\
\hline $\begin{array}{c}\text { "Pulp } \\
\text { Fiction" }\end{array}$ & $85.9 \%$ & $2.8 \%$ & $32.4 \%$ & $15.5 \%$ & $1.4 \%$ & $2.8 \%$ \\
\hline $\begin{array}{c}\text { "Once Upon } \\
\text { a Time in... } \\
\text { Hollywood" }\end{array}$ & $68.75 \%$ & $9.3 \%$ & $9.35 \%$ & $7.1 \%$ & $8.5 \%$ & $0.3 \%$ \\
\hline
\end{tabular}

Table 3. Semantic ambiguity of shit in "Pulp Fiction" and "Once Upon a Time in ... Hollywood"

\begin{tabular}{|c|c|c|c|c|}
\hline \multirow{2}{*}{ Film } & \multicolumn{4}{|c|}{ Meaning (function) } \\
\cline { 2 - 5 } & $\begin{array}{c}\text { An exclamation } \\
\text { of disbelief, } \\
\text { disgust, } \\
\text { disappointment, } \\
\text { emphasis }\end{array}$ & $\begin{array}{c}\text { Anything of } \\
\text { inferior quality, } \\
\text { pretentious, } \\
\text { meretricious trash }\end{array}$ & $\begin{array}{c}\text { To tease or attempt } \\
\text { to deceive, to lie to } \\
\text { someone, to respond } \\
\text { powerfully }\end{array}$ & $\begin{array}{c}\text { Excellent } \\
\text { admirable }\end{array}$ \\
\hline "Pulp Fiction" & $39.4 \%$ & $81.5 \%$ & $6.57 \%$ & $3.9 \%$ \\
\hline $\begin{array}{c}\text { "Once Upon a Time } \\
\text { in... Hollywood" }\end{array}$ & $42.9 \%$ & $45.7 \%$ & $11.4 \%$ & - \\
\hline
\end{tabular}

Table 4. Semantic ambiguity of goddamn in "Pulp Fiction" and "Once Upon a Time in ... Hollywood"

\begin{tabular}{|c|c|c|}
\hline \multirow{2}{*}{ Film } & \multicolumn{2}{|c|}{ Meaning (function) } \\
\cline { 2 - 3 } & $\begin{array}{c}\text { accursed, wretched, } \\
\text { nasty }\end{array}$ & $\begin{array}{c}\text { for euphony and rhythm of } \\
\text { emphasis }\end{array}$ \\
\hline "Pulp Fiction" & $33.3 \%$ & $66.6 \%$ \\
\hline "Once Upon a Time in... Hollywood" & $47.6 \%$ & $52.4 \%$ \\
\hline
\end{tabular}

Table 5. Semantic ambiguity of motherfucker in "Pulp Fiction" and "Once Upon a Time in ... Hollywood"

\begin{tabular}{|c|c|c|c|}
\hline \multirow{2}{*}{ Film } & \multicolumn{3}{|c|}{ Meaning (function) } \\
\cline { 2 - 4 } & $\begin{array}{c}\text { A despicable } \\
\text { person. A } \\
\text { moronic jerk }\end{array}$ & $\begin{array}{c}\text { An admirable or } \\
\text { prodigious } \\
\text { person }\end{array}$ & $\begin{array}{c}\text { A problem } \\
\text { or difficulty }\end{array}$ \\
\hline "Pulp Fiction" & $64.28 \%$ & $28.5 \%$ & $7.14 \%$ \\
\hline "Once Upon a Time in... Hollywood" & $47.6 \%$ & $52.4 \%$ & \\
\hline
\end{tabular}

Only rare Ukrainian words can convey this variety of meanings and match the same frequency of use. Consequently, the translator applied different lexical means to render semantics and maintain the corresponding tone in the target texts. Comparative analysis of the source and target scripts has been carried out to detect the techniques adopted by the translators. The translation solutions were analysed according to the following classification of translation techniques: (1) literal translation, (2) calque, (3) explicitation, (4) substitution, 
(5) transposition, (6) compensation, (7) omission, and (8) reformulation with a special emphasis on meaning in context (14). Among the mentioned techniques, calque and transpositions were not relevant for our data, so the classification reduced to literal translation, explicitation, compensation, omission and reformulations.

Literal translation entails the direct transfer of a word from a source language (SL) into a target language (TL) maintaining the semantics and the tone:

ST: You tried to fuck him.

TT: Ти намагався трахнути його! ("Pulp Fiction”)

ST: and I didn't believe them. So I guess I'm the fucking idiot.

TT: Чому я не вірила? Тому, що ідіотка притирена! (“Once Upon a Time in...

Hollywood")

Explicitation implies the use of specification, usually by using a word with more precise meaning:

ST: Oh, no fuckin' shit she'll freak.

TT: Та ні, вона гепнеться! ("Pulp Fiction")

ST: because I wanted some fucking rinky-dink movie career.

TT: я бзикнувся у великому, лусни його срака, кіно зніматись. (“Once Upon a Time in... Hollywood")

Substitution constitutes a typical subtitling strategy of using a shorter (but the same semantically) word in the translation still maintaining the tone of the original:

ST: You ain't got no problem, Jules, I'm on the motherfucker.

TT: У тебе немає жодної проблеми, Джулсе: я займаюся циим козлом! ("Рир Fiction")

Compensation entails resorting to the semantically equivalent but neutralized expression to compensate for stylistic losses in other parts of the film:

ST: What the fuck you up to?

TT: Що за фрігня? ("Pulp Fiction”)

ST: Fuck you, you fucking pig!

TT: Пішли ви, довбані свині! ("Once Upon a Time in... Hollywood”)

Omission happens mainly due to technical limitations, and may entail the deletion of words or phrases:

ST: 00:06:10,276 Cliff drives him everywhere now. Oh, fuck.

TT:____ ("Once Upon a Time in ... Hollywood")

ST: Well, if coming face-to-face with the failure that is your career ain't worth crying about, then I don't know what the fuck is.

TT: Коли хтось каже що твойй кар'єрі гаплик, то дідько знає що гірше. ("Onсе Upоп a Time in... Hollywood")

Reformulation is used to express idea in a different way, by rephrasing the source texts still retaining their meaning and social stylistic register (21).

Table 6. Translation techniques for rendering slang words in "Pulp Fiction" and "Once Upon a Time in ... Hollywood"

\begin{tabular}{|c|c|c|c|c|c|c|}
\hline & $\begin{array}{c}\text { Literal } \\
\text { translation }\end{array}$ & Explicitation & Substitution & Compensation & Omission & Reformulation \\
\hline $\begin{array}{c}\text { "Pulp } \\
\text { Fiction" }\end{array}$ & $31.73 \%$ & $6.07 \%$ & $39.75 \%$ & $15.45 \%$ & $21.34 \%$ & $6.34 \%$ \\
\hline $\begin{array}{c}\text { "Once Upon } \\
\text { a Time in... } \\
\text { Hollywood" }\end{array}$ & $30.98 \%$ & $26.03 \%$ & $48.8 \%$ & $16.8 \%$ & $21.72 \%$ & $1.35 \%$ \\
\hline
\end{tabular}

To verify the overall tendency of dealing with the transfer of slang words, the number of instances where the register has been toned up, maintained, toned down, neutralised or omitted (21), the techniques were rearranged according to this criterion. Thus, literal 
translation, explicitation and substitution are the instances of maintaining the register of the source words, while compensation tones up the target word, and omission neutralises it. Following Baker's ideas, we may define style maintenance, toning up or neutralization as translation strategies for rendering slang.

Table 7. Slang words' stylistic register in Ukrainian translation of "Pulp Fiction" and "Once Upon a Time in ... Hollywood"

\begin{tabular}{|c|c|c|c|c|}
\hline Slang word & Film & Maintained & Toned up & $\begin{array}{l}\text { Omitted } \\
\text { (neutralized) }\end{array}$ \\
\hline \multirow{2}{*}{ fuck } & "Pulp Fiction" & $78.23 \%$ & & $21.77 \%$ \\
\cline { 2 - 4 } & "Once Upon a Time in... Hollywood" & $76.2 \%$ & & $23.8 \%$ \\
\hline \multirow{2}{*}{ fucking } & "Pulp Fiction" & $51.7 \%$ & & $49.03 \%$ \\
\cline { 2 - 4 } & "Once Upon a Time in... Hollywood" & $66.54 \%$ & $6.48 \%$ & $26.98 \%$ \\
\hline \multirow{2}{*}{ godit } & "Pulp Fiction" & $68.75 \%$ & $8.35 \%$ & $22.9 \%$ \\
\cline { 2 - 5 } & "Once Upon a Time in... Hollywood" & $73.62 \%$ & $2.63 \%$ & $23.75 \%$ \\
\hline \multirow{2}{*}{ motherfucker } & "Pulp Fiction" & $100 \%$ & & \\
\cline { 2 - 5 } & "Once Upon a Time in... Hollywood" & $66.6 \%$ & $13.1 \%$ & $20.83 \%$ \\
\cline { 2 - 5 } & "Once Upon a Time in... Hollywood" & $84.4 \%$ & $8 \%$ & $7.6 \%$ \\
\hline
\end{tabular}

\section{DISCUSSION}

This case study has been based on the scripts of two films by Quentin Tarantino. Taking into account the statistics provided by WordSmith 6.0, slang words are among the most important linguistic tools, and their omission or neutralisation may entail significant losses.

The analysed slang words, of course, belong to the obscene vocabulary - "a type of language use in which the expression refers to something that is taboo and/or stigmatized in the culture; should not be interpreted literally; can be used to express strong emotions and attitudes" (22: 53). The words shit and fuck (fucking) from the analysed films can be used as representative examples; they literally refer to tabooed items: excrement and an act of copulation. However, the cases when they were used in their literal meaning are quite insignificant: fuck ("Pulp Fiction" 2.8\%, "Once Upon a Time in... Hollywood" 9.3\%).

Despite the fact that slang words may nominate things, people or concepts, in the analysed films, their functions are often reduced to emotional: fuck (85.9\% cases in "Pulp Fiction" and $68.75 \%$ in "Once Upon a Time in... Hollywood"), shit (39.4\% cases in "Pulp Fiction" and $42.9 \%$ in "Once Upon a Time in... Hollywood") goddamn (66,6\% in "Pulp Fiction" and 52.4\% in "Once Upon a Time in... Hollywood"). Quite often, they function as semantically devastated interjections or intensifiers as fucking (61\% in "Pulp Fiction" and $68 \%$ in "Once Upon a Time in... Hollywood").

Translating Quentin Tarantino's dialogue presents a considerable challenge to any translator because of the difficulties encountered while dealing with offensive and taboo elements, while at the same time having to abide by the technical requirements of this particular mode of audiovisual translation (22). Besides, according to J. Diaz-Cintas, the quality of audiovisual translation depends not only on the asymmetry between languages and cultures, but also on the conceptual perception of translation, based on the official position of the authorities and the dominant ideology (23). Ukrainian translators claim that no censorship but some inner restrictions influenced the process: "We were provided the detailed script to do our job professionally. Unfortunately, not all layers of meaning laid down by Tarantino worked well for our audience, as well as cross-allusions and selfquotations... We often quote the phrase of American colleagues: "Respect the domestic" (24). "If there is abusive or slang vocabulary in the source, avoiding it signifies hypocrisy and frightening self-censorship" (25). 
In this context, translation is always a compromise between the ethics of performers and the restrictions imposed by society and (or) producers or distributors of audiovisual products (26). Even in countries with strict regulation of the language of audiovisual products, substandard vocabulary finds its way into alternative non-professional translations, the so-called "fansubs" (14).

Commenting on the translation strategies, Oleg Kolesnikov, the translator of "Once Upon a Time in... Hollywood", emphasises that "a character may pronounce motherfucker with hatred, fear or some other emotion. The most important thing is rendering emotion. I usually offer several options: some harder, some softer. During the recording, the director chooses what is best" (24).

As mentioned, obscene words used by Quentin Taranitino's characters are slang words. Slang is a universal phenomenon that exists in the majority of cultures. Of course, the volume of slang, as well as its accessibility in the society or mass media, differ in different countries. Still, we can claim that despite the polysemy of most of the English words, the Ukrainian language can provide a number of social-semantic equivalents registered in the specialised dictionaries $(27,28)$, fully maintaining both the meaning and the tone of the source. Sometimes the colloquialisms have been suggested as equivalents instead of slang words, but the slight toning up was insignificant.

The translation techniques chosen for this study follow the classification by J. DíazCintas, P. Orero and A. Remael (18) but for calque and transpositions that were not peculiar for the data. Literal translation was registered in 31.73\% ("Pulp Fiction") and 30.98\% "Once Upon a Time in... Hollywood"), translators used explicitation strategy in $6.07 \%$ and $26.03 \%$ cases correspondingly, substitution was presumably the most productive $(39.75 \%$ and $48.8 \%$ ), compensation equalled $15.45 \%$ and $16.8 \%$. The overall quantity of omission was unexpectedly low $(21.34 \%$ and $21.72 \%)$. An insignificant number of slang words were reformulated at $6.34 \%$ and $1.35 \%$.

The overall hypothesis of the study was that translation solutions are primarily determined by the function performed by the slang word, and "harder" or "softer" options provided by the translators are those maintaining the obscene tone, neutralizing or toning up of the target word.

The following are some of the most illustrative examples of both films. As mentioned above, the word fucking was mostly used as an intensifier adjective. In most cases, it has been translated literally by using the corresponding Ukrainian slang word бляxa:

ST And if it's not the gooks, it's these old fuckin' Jews who've owned the store for 15 fuckin' generations.

ТТ Ну а якщзо це не якийсь вузькоокий, то старі довбані євреї, щзо володіють крамницею вже 15, бляха, поколінь! ("Pulp Fiction")

ST Fuckin' Marsellus knew it. And Antwan should've fuckin' better known better.

тТ Так от, бляха, Марселас про ие знав, і Антуану, дідько, теж треба було знати! ("Pulp Fiction")

ST: You're Rick fucking Dalton. Don't you forget it.

TT: Гей! Ти - Рік, бляха, Долтон! Не забувай! ("Once Upon a Time in... Hollywood”)

The slang word fuck actually embraces two concepts: 'to copulate with' and, figuratively, 'to deceive', and has no intrinsic meaning, but has an offensive force (29). Some scholars claim that fuck derivatives invoke the physiological and emotional intensity of sexual experience; transferring it into other domains, where it is used to characterize situations, activities and experiences as intensely good or intensely bad (30). This is best exemplified by the use of fucking to express both negative (Fuckin' Marsellus knew it!) and positive (You're Rick fucking Dalton. Don't you forget it!) meanings.

The counterparts for fucking meaning 'displeasing', 'despicable' are usually colloquial adjectives довбаний, чортовий, свинячий, кінчений: 
ST: So pretty please, with sugar on top, clean the fuckin' car.

TT: Не відмовте в любязності, вимийте чортову тачку! ("Pulp Fiction”)

ST: Oh, that fucking bitch!

TT: Yортове стерво! (“Once Upon a Time in... Hollywood")

Explicitation implies introducing something in the translation which was only implicated in the original, but can be derived from the context (31). Explicitation aiming at specifying the level of emotion helps to maintain the overall tone:

ST: Don't fuckin' talk to me that way, man.

TT: Не жени біса, приятелю! ("Pulp Fiction”)

ST: That's the fucking problem! - Come on.

TT: Щоб їм повилазило! ("Once Upon a Time in... Hollywood”)

The translators didn't opt for omission very often. The dubbing director of "Once Upon a Time in... Hollywood" confirmed that "sometimes you notice mounting flaws and inconsistencies. Sometimes you have to smooth them. For example, when in the original the phrase does not quite work with the video, or when the editing joint shows the jaw of the character, who is standing half-turned to the camera, is still moving, and the sound is gone" (24). Presumably, the cases where the slang words were eliminated might at least partially have been technically justifiable.

Rendering fuck required similar techniques: literal translation, compensation or omission. As mentioned above, fuck was mostly used as an exclamation to express negative emotions. Most often it was literally translated as бляха:

ST: What the fuck is this place?

TT: Це що, бляха, таке? ("Pulp Fiction")

ST: What the fuck?

TT: Що за бляха ? ("Once Upon a Time in... Hollywood")

Sometimes the translators resorted to other slang words (капець, фігня) or colloquialisms падло, Якого ж біса! , йти в ...., щзоб тебе!:

ST: I'm fucked. Oh, fuck. Oh, fuck.

TT: Мені каnец, ! Yopm! Kaneu,b! ("Pulp Fiction”)

ST: Fuck you.

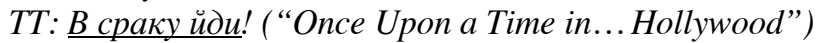

If fuck implied some negative actions such as 'to cheat', 'to swindle', 'maltreat', 'take advantage of', 'to botch and confuse', 'ruin' the translators used explicitation, usually by providing a word with more precise meaning, often a colloquialism:

ST: It was out five days, and some dickless piece of shit fucked with it.

TT: Я ̈̈жджу на ній п'ятий день $і$ якийсь гівнюк иї nодряпав. ("Pulp Fiction")

ST: I fucked this whole thing up, Sam.

TT: Я всю сцену пересрав. ("Once Upon a Time in... Hollywood")

ST: .... as sure as God made little green apples... that one of these days, that Polish prick's gonna fuck things up.

TT: Він знає, що не пройде й року, як хтивий польський жеребець піде наліво і Шерон згадає про Джея. ("Once Upon a Time in... Hollywood”)

Explicitation aims at expressing situation elements, which remained unexpressed (at least verbally) in the source text. The mentioned scenes containing slang words described respectively: property (car) damage, sham acting and sexual promiscuity. The translators resorted to noдpяnamu 'to dent, scratch, scrape or rip', nepecpamu 'to spoil something, especially to spoil a person's chances', and xодити наліво 'to behave in a sexually promiscuous fashion' to make information clearer.

If fuck meant 'misfortune, unpleasantness, hostile behavior or ill-treatment' it was usually omitted or neutralized (compensated) by $щ_{о}$ :

ST: Get the fuck out my face with that shit! 
TT: Досить нести нісенітниці! ("Pulp Fiction”)

ST: What the fuck's happenin'?

TT: Що за чорm! ("Pulp Fiction”)

ST: Hey, jackass, this is our series lead. What the fuck are you thinking?

TT: Гей, козляро, це - один з головних акторів! Ти щ, собі думаєш? ("Onсе Uроп а Time in... Hollywood")

One of the possible reasons for the slang word neutralisation is technical restriction: the need for synchronising the translation with the audio and visual cues of the original (18). The phonetic synchrony implies concentration on syllables, open vowels, bilabial or labiodental consonants, adjusting of the rhythm etc. Ukrainian $щ_{о}$ in the mentioned examples seems to adhere to synchronisation.

When characterizing something as 'excellent, admirable', fuck was rendered through colloquialism:

ST: that-that's one shit-fuck crazy weapon

TT: Так! I ие, срака-мотика, сатана, а не зброя! ("Once Upon a Time in... Hollywood")

As mentioned above, shit was often used as an exclamation of disbelief, disgust, disappointment, emphasis, and the most common Ukrainian counterpart was yopm. Ukrainian чopm doesn't make references to human faeces but still used to disqualify people, objects and situations:

ST: $\underline{\text { Shit }}$, yeah, negro!

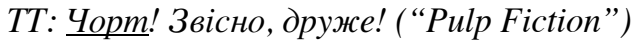

ST: Wait a minute. Oh, shit. Sorry, I forgot my knife in the car.

TT: Хвилинку! Oт чорт! Я забула свій ніж! ("Once Upon a Time in... Hollywood”)

Author's neologisms, suggested as equivalents were welcomed by the audience:

ST: Holy shit.

TT: Йоaнi ŭozu! ("Once Upon a Time in... Hollywood”)

ST: Holy shit. Heh. That was Polanski.

TT: ̆ㅡога за ногу! Це ж був Поланський! ("Once Upon a Time in... Hollywood”)

ST: Holy shit. Goddamn it.

TT: Йога за ногу, щоб я скиснув! ("Once Upon a Time in... Hollywood”)

If shit meant 'anything of shoddy and inferior quality, pretentious and meretricious trash', the translators used the slang word хрінь or colloquialisms гівно, лайно maintaining both the meaning and the tone of the utterance:

ST: I been sayin' that shit for years, and if you heard it, that meant your ass.

TT: Я багато років говорив це лайно, $і$ для тих, хто це слухав, це означало кінецьь. ("Pulp Fiction")

ST: And I think all that "lethal weapon" shit is just an excuse so you dancers never have to get in a real fight.

TT: Вся ия хрінь про летальну зброю - це така хрінь, щоб такі йолопи як ти зіскочили з базару! ("Once Upon a Time in... Hollywood")

ST: Piece of shit.

TT: Om ziвно! ("Once Upon a Time in... Hollywood")

Words for faeces are typical taboo swear words in many European languages and shit is, literally, the "dirtiest' of all 'dirty words' in English" (32: 58), like гівно, лайно in Ukrainian. It seems Ukrainians prefer to use гівно, лайно when describing a misfortune, a trouble or difficulty, anything of poor quality, etc., pointing to exactly the same referent as the original shit.

Sometimes the translators explicitated the concept, using a word with more precise meaning, often a colloquialism: манатки, задуn'я etc:

ST: Get the wardrobe off, get your shit, and get fucked! 
TT: Іди знімай костюм збирай манатки і котися в сраку! ("Once Upon a Time in... Hollywood")

ST: Puerto Canyon or some shit. I don't know.

TT: Каньйон Пуерто чи ще якесь задуn'я. ("Once Upon a Time in... Hollywood")

In the examples, shit mainly refers to some real objects (face piercing, clothes, remote place or an old car), and these instances were addressed in translation by the words containing corresponding semes: манатки 'shabby clothing', задуn's 'a highly undesirable town or place'.

Explicitation was often applied to render the meanings 'to tease or attempt to deceive', 'to lie to someone', 'to respond powerfully, esp. with alarm, anger or panic':

ST: We don't wanna fuck your shit up.

TT: Все буде нормально, ми не хочемо тебе підставляти. ("Pulp Fiction”)

ST: So, Rick, who's gonna kick the shit out of you next week?

TT: Тож, Рік, хто тобі наваляє наступного тижня? ("Onсе Uроп а Tiте in... Hollywood")

The meanings 'to tease or attempt to deceive', 'to lie to someone', 'to respond powerfully, esp. with alarm, anger or panic' are rendered by corresponding slang and colloquial words: nidставляти 'to get someone blamed and into trouble', наваляти 'to hit someone'.

Omission was not typical for this slang words. Taking into consideration the mentioned solutions for rendering slang words, the implementation of omission and neutralisation can be technically justified by the spatio-temporal rather than censorship or linguistic constraints:

ST: Normally both your asses would be dead as fuckin' fried chicken, but you happened to pull this shit while I'm in a transitional period, and I don't wanna kill you; I wanna help you.

TT: За стандартної ситуації я б вас обох вже вбив, але ви все ие влаштували, коли у мене перехідний період, $і$ я не хочу вас вбивати, я хочу вам допомогти. ("Риlр Fiction")

ST: Get your shit together.

TT: Ану збирайся! ( "Once Upon a Time in... Hollywood”)

The slang word goddamn was mostly used as an exclamation to express negative emotions and was largely literally translated as Йоперний балет!, Слизня мені в гузно!, Щоб я скиснув!, А щзоб тобі!:

ST: Goddamn it.

TT: Йоперний балет! ( "Once Upon a Time in... Hollywood”)

ST: Ah. G-goddamn it to hell. I'm-I'm sorry about that.

TT: Чорт, слизня мені в гузно! ("Once Upon a Time in... Hollywood")

When used as an adjective 'accursed, wretched, nasty' goddamn in Ukrainian translation was rendered as псячий, довбаний, чортовий, вражий:

ST: I gotta do Italian goddamn movies!

TT: Гратиму у псячих макаронників. ("Once Upon a Time in... Hollywood")

ST embarrassed yourself like that in front of all those goddamn people!

TT: I так зганьбився перед цими чортовими покидьками! ("Onсе Upоn a Time in... Hollywood")

The omission strategy is relatively insignificant:

ST: Well, the fucking hippies aren't, that's for goddamn sure.

TT: Hy, у довбаних хіni - нi! ( "Once Upon a Time in... Hollywood”)

As mentioned above, motherfucker may nominate 'A despicable person. A moronic jerk' and is translated as вилупок, виродок, дебіл, козел:

ST: They're your clothes, motherfucker. 
TT: Це твій одяг, дебіл! ("Pulp Fiction”)

ST: I just thought it was some coldblooded shit to say to a motherfucker...

TT: Я завжди думав, щзо ще лише круті слова, які можна казати вголос, перш, ніж вбити якогось вилупка. ("Pulp Fiction")

Sometimes the word is neutralised by standard counterparts:

ST: Fuck! Fuck! Fuck! Motherfucker!

TT: Чорт, чорт, щоб тебе, чорт забирай. Ти - дурепа! ("Pulp Fiction”)

Recurrent connection between the certain meanings and their translation counterparts provides some correspondences that may be treated in future as regular or systematic (See Table 13).

Table 8 Ukrainian equivalents for fucking, fucking, shit, goddamn, motherfucker in "Pulp Fiction" and "Once Upon a Time in... Hollywood" translations into Ukrainian

\begin{tabular}{|c|c|c|c|}
\hline \multirow[t]{2}{*}{ Slang word } & \multirow[t]{2}{*}{ Meaning (Function) } & \multicolumn{2}{|c|}{ Counterparts } \\
\hline & & Slang & Colloquialisms \\
\hline \multirow[t]{2}{*}{ fucking } & 'intensifier' & бляха & \\
\hline & 'displeasing, despicable' & довбаний, кінчений & чортовий, свинячий \\
\hline \multirow[t]{3}{*}{ fuck } & $\begin{array}{l}\text { 'an exclamation of } \\
\text { annoyance, disgust, } \\
\text { disappointment' }\end{array}$ & $\begin{array}{c}\text { бляха, } \\
(\text { бляха-муха) }\end{array}$ & $\begin{array}{c}\text { Падло! } \\
\text { Якого ж біса! Йти в } \\
\text { сраку (дупу) } \\
\end{array}$ \\
\hline & 'to botch and confuse, ruin' & & пересирати \\
\hline & 'misfortune' & & гаплик \\
\hline \multirow[t]{3}{*}{ shit } & $\begin{array}{c}\text { 'an exclamation of disbelief, } \\
\text { disgust, disappointment, } \\
\text { emphasis' }\end{array}$ & $\begin{array}{c}\text { Йохані йоги! Йога за } \\
\text { ногу! }\end{array}$ & Чopm! \\
\hline & $\begin{array}{l}\text { 'anything of shoddy and } \\
\text { inferior quality, pretentious } \\
\text { and meretricious trash' }\end{array}$ & $\begin{array}{l}\text { хрінь, } \\
\text { фігня }\end{array}$ & гівно \\
\hline & $\begin{array}{l}\text { 'to respond powerfully, esp. } \\
\text { with alarm, anger or panic' }\end{array}$ & & наваляти, надерти сраку \\
\hline \multirow[t]{2}{*}{ goddamn } & $\begin{array}{c}\text { 'an exclamation of disbelief, } \\
\text { disgust, disappointment, } \\
\text { emphasis' }\end{array}$ & $\begin{array}{c}\text { бляха, Йоперний } \\
\text { балет! }\end{array}$ & $\begin{array}{c}\text { Слизня мені в гузно! } \\
\text { Щоб я скиснув! А щзоб } \\
\text { тобі! }\end{array}$ \\
\hline & 'accursed, wretched, nasty' & довбаний & $\begin{array}{c}\text { чортовий, вражий, } \\
\text { псячий }\end{array}$ \\
\hline motherfucker & $\begin{array}{c}\text { 'a despicable person, } \\
\text { moronic jerk' }\end{array}$ & вилупок, дебіл, козел & виродок \\
\hline
\end{tabular}

\section{Conclusion}

After the cases of slang usage and its translation in Tarantino's "Pulp Fiction" and "Once Upon a Time in... Hollywood" were collected and analysed semantically and pragmatically, they were allocated according to the translation strategies used for slang rendering, and quantified so certain conclusions can be drawn.

Slang is one of the most powerful linguistic tools to depict characters, their feelings and emotions. Its neutralising or omission may influence the intended function implied by the author. The present study shows that in spite of notorious national uniqueness, linguistic ambiguity and complex functionality of the slang words, in most cases, they are translatable successfully without significant losses.

English slang words mostly have counterparts (often more than one) in Ukrainian slang or, at least, in colloquial speech. In both analysed films the translators maintained the tone and the meaning in more than $2 / 3$ cases $(76.6 \%$ in "Pulp Fiction" and $76.4 \%$ in "Once Upon a Time in ....Hollywood"). The translator succeeded in transferring SL slang into TL 
slang primarily if the meaning was transparent (denoted despicable humans, anything of shoddy and inferior quality etc).

The translators toned up the utterances suggesting Ukrainian standard words as counterparts to English slang in $8.1 \%$ cases in "Pulp Fiction" and $7.37 \%$ in "Once Upon a Time in... Hollywood". Transferring SL slang into TL colloquialisms could be considered less successful and usually embraced words with a vaguer meaning (exclamations of disbelief, disgust, disappointment, emphasis).

The words were omitted in $25.25 \%$ cases in "Pulp Fiction" and $23.84 \%$ in "Once Upon a Time in ...Hollywood". More research is needed to provide more insights into extralinguistic constraints the translators confront when omitting slang words.

The study suggests that the techniques involved show a certain correlation between the semantic transparency of the slang word and the strategy chosen. The list of EnglishUkrainian slang word regular equivalents can be applied in further translations.

\section{References}

1. R. Brody, Review: Quentin Tarantino's obscenely regressive vision of the sixties in "Once upon a time ... in Holliwood". The Newyorker, July 27 (2019)

2. J. Chaney, On the Troubling Subtext of Once Upon a Time in Hollywood. Vulture.com. August 9 (2019)

3. B. Fretts, A Pop-Culture Glossary for 'Once Upon a Time ... in Hollywood'. New York Times, July 30 (2019)

4. A.M. Fernández Dobao, Linguistic and cultural aspects of the translation of swearing: The Spanish version of Pulp Fiction, Babel 52(3) (2006)

5. F. Chaume, Film studies and translation studies: Two disciplines at stake in audiovisual translation, Meta: Transl. J., 49(1), 12-24 (2004)

6. E. Mattiello, The pervasiveness of slang in standard and non-standard English. Mots Palabras Words, 6, 7-41. (2005)

7. R.A. Spears, American Slang Dictionary: The Ultimate Reference to Nonstandard Usage, Colloquialisms, Popular Jargon and Vulgarisms (McGraw-Hill, 2006)

8. T. Thorne, Dictionary of contemporary slang (Bloomsbury Publishing, 2014)

9. B. A. Kipfer, R. L. Chapman, Dictionary of American slang (Harper Collins, 2010)

10. J. Ayto, J. Simpson, Oxford dictionary of modern slang (Oxford University Press, 2010)

11. J. Green, Odd Job Man: Some Confessions of a Slang Lexicographer (Random House, 2014)

12. F. Mason, American Gangster Cinema: From "Little Caesar" to "Pulp Fiction" (Springer, 2002)

13. M. Dore, The Italian Dubbing of Dialects, Accents and Slang in the British Dark Comedy Drama 'Misfits', Status Quaestionis, 11 (2016)

14. J. Díaz-Cintas, P. Muñoz Sánchez, Fansubs: Audiovisual translation in an amateur environment. Jostrans: The J. of Spec. Transl., 6, 37-52 (2006)

15. P. Baker, Querying keywords: Questions of difference, frequency, and sense in keywords analysis. J. Engl. Linguist. 32(4), 346-359 (2004)

16. N.C. Tardzenyuy, Revisiting translation strategies and techniques. International Journal of Comparative Literature and Translation Studies, 4.4, 48-56 (2016)

17. M. Baker, In other words: A coursebook on translation (Routledge, 2018) 
18. J. Díaz-Cintas, P. Orero, A. Remael, Media for all: subtitling for the deaf, audio description, and sign language, 30 (2007)

19. E. Mattiello, Keeping lexical complexity in slang translation. Lexical complexity: Theoretical assessment and translational perspectives, 65-83 (2007)

20. D. Pujol, The translation and dubbing of 'fuck'into Catalan: The case of From Dusk till Dawn. The J. of Spec. Transl., 6, 121-133 (2006)

21. J. C. Filipec Ceská lexikologie (Academia, Praha, 1985)

22. J. J. Ávila-Cabrera, The treatment of offensive and taboo language in the subtitling of Reservoir Dogs into Spanish. TRANS: revista de traductología, 20, 25-40 (2016)

23. J. Díaz-Cintas, Clearing the smoke to see the screen: Ideological manipulation in audiovisual translation. Meta: Transl. J., 57(2), 279-293 (2012)

24. O. Litskevych, Translator of 'Once Upon a Time ... in Hollywood': it was not a great deal to find Ukrainian equivalents for American obscenities. Quite the opposite (in Ukrainian), Yod. Media, August 28 (2019)

25. O. Litskevych, Dubbing director of “Once Upon a Time ... in Hollywood”: Tarantino's peculiarities that could be missed by Ukrainian audience (in Ukrainian). Yod. Media, August 29 (2019)

26. J. Santaemilia, The translation of sex-related language: The danger (s) of selfcensorship (s). TTR: traduction, terminologie, rédaction, 21(2), 221-252 (2008)

27. T. Kondratiuk, Ukrainian Modern Slang Dictionary (Folio, Kharkiv, 2006)

28. L. Stavyts'ka, Shorter dictionary of Ukrainian jargon (in Ukrainian) (Krytyka, Kyiv, 2003)

29. S. Pinker, The stuff of thought: Language as a window into human nature (Penguin, 2007)

30. P. Hobbs, Fuck as a metaphor for male sexual aggression. Gender \& Language, 7.2 (2013)

31. E. Mattiello, Keeping Lexical Complexity in Slang Translation. Lexical complexity. Theoretical assessment and translational perspectives, 1, 121-140 (2007)

32. L.G. Andersson, P. Trudgill, Bad language (Blackwell by arrangement with Penguin Books, 1990) 